\title{
Tool Guarantee of Intermittent Cutting Processes
}

Evgeniy Alekseevich Kudryashov, Igor Mikhailovich Smirnov

Scientific Research Engineering Institute. 143912, Moscow region, Balashikha, Shosse Enthuziastov 6. Russia. E-mail: kraxmall1@yandex.ru, i.m.smirnov@aoniii.ru

Reforming obsolete technologies, increasing production of new machines and devices are impossible without modern and reliable instrumentation. The high structural complexity of the manufactured parts creates problems for the use of a blade tool that, along with high hardness, has considerable brittleness. As a rule, the processing of intermittent surfaces by turning is accompanied by chipping of the cutting edges.

The disadvantages of alternative grinding technologies are the high cost of equipment, low productivity, as well as the problems of forming the required quality parameters of the surface layer due to the specificity of operation of the grinding tool.

The solutions protected by patents of the Russian Federation, allowing to exclude negative factors of intermitted cutting are offered. The scientific novelty of the decisions made is to give the damping tool a special position that excludes negative interaction between sharp tip of cutting element and intermittent surface, which provides the possibility of stable operation of brittle tool material on the basis of the developed mechanism for controlling the position of the cutter tip.

Keywords: Composites, intermittent surface, interrupted cutting, damping, quality of surface.

\section{References}

[1] KUDRYASHOV, E., MALYKHIN, V., YATSUN, E., PAVLOV, E., NOVIKOV, S. (2011). Increase in stability of the process of turning by the damping cutter. Proceedings of South-West State University. Series Engineering and Technology. Vol. 36, No. 3, pp. 122-125. SWSU, Kursk. ISSN 2223-1560.

[2] SZTANKOVICS, I., KUNDRÁK, J. (2014). Effect of the inclination angle on the defining parameters of chip removal in rotational turning. Manufacturing Technology. Vol. 14, No. 1, pp. 97-104. ISSN 1213-2489.

[3] KUDRYASHOV, E., SMIRNOV, I. (2013). Effective operation of the tool from a composite in case of high-speed milling of carving. Metal Working and Material Science. Vol. 59, No. 2, pp. 25-32. NSTU, Novosibirsk. ISSN 1994-6309.

[4] BACH, P., POLÁČEK, M., CHVOJKA, P., DROBÍLEK, J. (2014). Dynamic Forces in Unstable Cutting during Turning Operation. Manufacturing Technology. Vol. 14, No. 1, pp. 3-8. ISSN 1213-2489.

[5] KUDRYASHOV, E., SMIRNOV, I., (2013). Application of a method of management of the cutting part of the tool for increase in efficiency of process of intermittent cutting. Proceedings of South-West State University. Series Engineering and Technology. No. 4, pp. 23-28. SWSU, Kursk. ISSN 2223-1560.

[6] KUDRYASHOV, E., SMIRNOV, I. (2014). Search of optimal solutions when designing processes of machining. Systems. Methods. Technologies. Vol. 23, No. 3, pp. 94-98. BrSTU, Bratsk. ISSN 2077-5415.

[7] KUDRYASHOV, E., SMIRNOV, I., YATSUN, E. (2014). Choice of tool, ensuring processes of finish machining of structurally difficult surfaces of details. Science Intensive Technologies in Mechanical Engineering. Vol. 42, No. 12, pp. 10-14. Mashinostroenie, Moscow. ISSN 2223-4608.

[8] KUDRYASHOV, E. (2014). The choice of a basic detail for pilot study of a method of handling of structurally difficult screw surfaces of details for a shaft class. Vestnik YuZGU. Series Engineering and Technology. Vol. 57, No. 6 pp. 26-32. SWSU, Kursk. ISSN 2223-1560.

[9] KUDRYASHOV, E., SMIRNOV, I. (2014). Choosing rational brand of the tool material. Systems. Methods. Technologies. Vol. 22, No. 2, pp. 118-125. BrSTU, Bratsk. ISSN 2077-5415.

[10] KUDRYASHOV, E., SMIRNOV, I. (2014). To the choice of a rational method of maintenance of worn-out surfaces of details. Proceedings of South-West State University. Series Engineering and Technology. Vol. 42, No. 12, pp. 10-14. SWSU, Kursk. ISSN 2223-1560.

[11] KUDRYASHOV, E., SMIRNOV, I. (2015). Classification of structural complex parts surfaces as preparatory stage design technology machining. Fundamental and applied problems of Engineering and Technology. Vol. 310 , No. 2, pp. 89-94. State University ESPC, Orel. ISSN 2073-7408. 
[12] SMIRNOV, I. (2012). Increase in process of machining performance of structurally complex details of machines. 224 p. Triumph, Moscow. ISBN 978-5-89392-576-0.

[13] SMIRNOV, I. (2014). Instrumental ensuring of machining processes of structurally complex details of machines. 128 p. Triumph, Moscow. ISBN 978-5-89392-607-1.

[14] SMIRNOV, I., KUDRYASHOV, E., YATSUN, E. Patent for useful model, request No. 2013103125. A method of machining surfaces by cutting with strike. 23.01.2013.

[15] NOVIKOV, S., MALYKHIN, V., YATSUN, E., KUDRYASHOV, E., DOMAREV, N. Patent. RU 2479385. The damping cutter with regulated rigidity. 20.04.2013.

[16] KUNDRAK, J., RACZKOVI, L., GYANI, K., DESZPOTH, I. (2014). A method for planning the cutting ability of CBN tools. Manufacturing Technology. Vol. 14, No. 2, pp. 206-213. ISSN 1213-2489.

Copyright (C) 2017. Published by Manufacturing Technology. All rights reserved. 